Sebastian Gałecki

Akademia im. Jana Długosza, Częstochowa

e-mail: etyk@onet.eu

\title{
Warunki brzegowe etyki chrześcijańskiej
}

DOI: http://dx.doi.org/10.12775/RF.2017.038

\section{Wprowadzenie}

Istnieją takie pojęcia, których równościową i zupełną definicję jest niezwykle trudno ustalić. Sądzę, że do nich należy także „etyka chrześcijańska": idea, o którą toczą się spory od blisko dwóch tysięcy lat. Trudność w jej precyzyjnym zdefiniowaniu wynika z wielu przyczyn, przede wszystkim jednak z postulowanej przez licznych krytyków wewnętrznej sprzeczności terminu, tzn. z relacji zakresowego wykluczania się rzeczownika „etyka” oraz przymiotnika „chrześcijańska”. Rozważeniu tego problemu - i związanych z nim innych kwestii - poświęcone zostały niedawno dwa artykuły: próba rozstrzygnięcia, czy możliwe jest istnienie filozofii o proweniencji chrześcijańskiej ${ }^{1}$ oraz naszkicowanie relacji tworzących „rodzinę” etyki chrześcijańskiej, w skład której wchodziłaby także moralność chrześcijańska, teologia moralna i etyki niechrześcijańskie ${ }^{2}$.

Niniejszy artykuł zamyka trylogię poświęconą idei filozofii i etyki chrześcijańskiej, chcąc podać możliwie pełną i ścisłą definicję tej idei. Podtrzymując tezę, że wieki dyskusji na jej temat dowodzą niemożności

1 S. Gałecki, O możliwości istnienia filozofii chrześcijańskiej, „Ruch Filozoficzny”, t. 72, 2006, nr 3, s. 117-132.

2 S. Gałecki, Etyka chrześcijańska i jej rodzina, w: Etyka chrześcijańska - między tradycja a wspótczesnością. Studia i szkice, red. P. Duchliński, E. Podrez, WAM, Kraków 2016, s. 93-123. 
podania definicji równościowej, uciekniemy się do innego typu definicji, mianowicie: spróbujemy przedstawić definicję warunkowa, tzn. taka, w której nie występuje klasyczna równoważność między definiendum a definiensem, lecz podane zostają warunki konieczne (w wersji słabszej: wystarczające) dla identyfikacji danego przedmiotu definicji.

Podobne listy znajdziemy w kilku tekstach poświęconych problemowi filozofii i etyki chrześcijańskiej; wydaje się jednak, że autorzy nie traktują wymienionych przez siebie cech jako definicji warunkowej. Postrzegane są one tam raczej jako próba opisu, przybliżenia czytelnikowi charakterystycznych elementów omawianego nurtu. Wojciech Chudy, na przykład, wskazuje na trzy cechy filozofii chrześcijańskiej: „maksymalizm zadań, perennialność (wieczystość i ponadkulturowość) głównych tez oraz niesprzeczność z prawdami wiary"3. Krzysztof Stachewicz, pisząc o filozofii chrześcijańskiej sensu stricto, uznaje ją za "taki typ filozofii, w której do głosu dochodzi afirmatywne podejście do dziedzictwa myślowego, intelektualnego chrześcijaństwa" oraz - co za tym idzie - filozofię otwartą na tradycję teologiczną i odrzucającą wszystko to, co jest radykalnie sprzeczne $\mathrm{z}$ „duchem prawdy niesionej przez chrystianizm" ${ }^{4}$. Jeszcze inne cechy wymienia Étienne Gilson czy Jacques Maritain.

Pójdźmy zatem dalej i zaproponujmy nie zestaw mniej lub bardziej powszechnych cech etyki chrześcijańskiej, lecz kompletny zbiór warunków koniecznych i wystarczających, by danego myśliciela, dzieło czy system uznać za wyczerpujący desygnat etyki chrześcijańskiej. Oczywiście, poniższa lista w żadnym wypadku nie ma charakteru dogmatycznego i wręcz domaga się krytycznej analizy i ewentualnej korekty ze strony czytelników oraz polskiego środowiska filozoficznego, o co autor uprzejmie prosi.

\section{Warunek pierwszy: moralna przyjaźń}

„W bardziej potocznych i publicystycznych dyskusjach nad chrześcijańskością filozofii zwycięża proste odróżnienie filozofii współczesnej od tomizmu", pisał Mieczysław Gogacz. Warszawski myśliciel chciał chyba przez to powiedzieć, że czymś powszechnym jest utożsamianie filozofii i etyki chrześcijańskiej z tomizmem. Utożsamienie powszechne, ale

3 W. Chudy, Filozofia chrześcijańska - rozum i wiara, „Ethos” 2007, nr 3-4(79-80), s. 59.

4 K. Stachewicz, O filozofii chrześcijańskiej. Kilka uwag z perspektywy historycznej i futurologicznej, „Logos i Ethos” 2013, nr 2(35), s. 230-231.

5 M. Gogacz, Czym jest filozofia chrześcijańska, "Za i Przeciw” (5 kwietnia) 1981, nr 14 , s. 6 . 
błędne. Oczywiście nie przez przypadek tomizm - wprost odwołujący się do dziedzictwa św. Tomasza z Akwinu - może jako pierwszy kojarzyć się z chrześcijaństwem, a przynajmniej z katolicyzmem: przez wiele wieków uchodził bowiem za oficjalną doktrynę filozoficzną Kościoła.

Jest to jednak całkowicie błędna interpretacja i na poparcie tej tezy można przytoczyć podpisany przez Jana Pawła II dokument katolickiego Magisterium: nie należy sądzić, „jakoby istniała jakaś oficjalna filozofia Kościoła". Co więcej: nie tylko nie istnieje jakaś o f i c j a ln a etyka chrześcijańska, lecz przede wszystkim nie istnieje j e $\mathrm{d} n$ a etyka chrześcijańska, gdyż „mówiąc o filozofii chrześcijańskiej, mamy na myśli wszystkie ważne kierunki myśli filozoficznej, które nie powstałyby bez bezpośredniego lub pośredniego wkładu wiary chrześcijańskiej" ${ }^{\prime}$. Skoro „wszystkie ważne kierunki”, to mówienie o etyce chrześcijańskiej jest poprawne wyłącznie $w$ dwóch sensach: etyka chrześcijańska jako rodzina czy grupa poszczególnych koncepcji, „które nie powstałyby bez wkładu wiary chrześcijańskiej" lub jako właśnie jedna z tych licznych koncepcji, w żaden sposób nie mogąca sobie rościć pretensji do wyłączności albo szczególnej pozycji w świecie christianitas.

Pluralistyczne interpretowanie terminu „etyka chrześcijańska” otwiera zupełnie nowy horyzont znaczeń! Okazuje się bowiem, że mamy do czynienia nie tylko z konkurencją o "rząd dusz” pomiędzy etyką chrześcijańską a etykami niechrześcijańskimi, ale także ze sporem pomiędzy moralistami przyznającymi się do proweniencji chrześcijańskiej. Wszelki spór zaś uniemożliwia stagnację, przyjęcie "końca historii", ukontentowanie własną wyższością i zupełnością7. Przeciwnie: dostrzegamy żywy i twórczy ferment, gdy tylko uznamy, że etyka chrześcijańska „nie stanowi monolitu myślowego. Przeciwnie, jest to raczej zbiór rozmaitych nurtów, w swoich założeniach i rozwiązaniach nieraz znacznie od siebie oddalonych, o najróżniejszym zabarwieniu, a często jeszcze bardzo subtelnych odcieniach, przy tym, w mniejszym lub większym stopniu wzajemnie na siebie oddziałujących" ${ }^{\prime \prime}$. Przyjęcie takiej złożonej, wewnętrznie różnorodnej i dynamicznej koncepcji etyki chrześcijańskiej pozwala skupić się nie tyle na tym, co odróżnia ją od innych koncepcji, ile raczej na spoiwie łączącym wszystkie nurty dookreślające się przymiotnikiem „chrześcijański”" . Ta perspektywa przynosi jednak nie tylko

6 Jan Paweł II, Encyklika "Fides et ratio" do Biskupów Kościoła katolickiego o relacjach między wiara a rozumem, Rzym 1998, pkt 76.

7 Zob. P. Duchliński, A. Kobyliński, R. Moń, E. Podrez, Inspiracje chrześcijańskie w etyce, WAM, Kraków 2016, s. 99-101.

8 J. Durczewski, Z refleksji nad chrześcijańska myśla filozoficzna (Geneza - rozwójaktualność), „Acta Universitatis Nicolai Copernici. Filozofia” 1983, z. 143(7), s. 136-137 .

9 Uważna lektura Zarysu etyki ogólnej pozwala dostrzec, iż nawet tak - wydawałoby się - „fundamentalistyczny tomista”, za jakiego uważany był niedawno zmarły 
nowe, ciekawe odkrycia, lecz także zagrożenie: co zatem stanowi jądro, istotny zwornik tych różnych nurtów? Powiedzieć: „chrześcijaństwo", to jakby nic nie powiedzieć; kryteria te muszą zostać dość precyzyjnie opisane, jeśli chcemy posługiwać się terminem „etyka chrześcijańska”.

Wybitny prawosławny bioetyk Hugo Tristram Engelhardt ukuł trzy interesujące nas pojęcia: "moralność wypełniona treścią” (content-full morality) oraz „moralna obcość” i „moralna przyjaźń". Pierwsze z nich przeciwstawione jest moralności czysto formalnej: uznaniu jakiegoś autorytetu wyłącznie werbalnie, lecz nie faktycznie. W zależności od tego, w jakiej relacji do tak zdefiniowanej moralności się pozostaje, można zostać uznanym albo za moralnych przyjaciół (moral friends), albo za moralnie obcych (moral strangers). Zacytujmy nieco dłuższy fragment The Foundations of Bioethics.

„Obcymi moralnie" są te osoby, które nie podzielają w wystarczającym stopniu przesłanek moralnych czy zasad dowodzenia i wnioskowania, pozwalających rozwiązać moralne kontrowersje przy pomocy solidnych, racjonalnych argumentów; lub też te osoby, które nie podzielają zgody co do autorytetu osób i instytucji mających rozstrzygać kontrowersje moralne. Moralność wypełniona treścią zapewnia obszerne wytyczne dotyczące tego, co jest słuszne lub niesłuszne, dobre lub złe, ponad bardzo ogólną zasadę, że nie można wykorzystywać drugiego człowieka bez jego zgody. „Moralnymi przyjaciółmi” są ci, którzy podzielają „moralność wypełnioną treścią" w wystarczającym stopniu, by móc rozwiązywać kontrowersje moralne przy pomocy racjonalnych argumentów moralnych lub przez odwołanie się do wspólnie uznawanego autorytetu moralnego, którego jurysdykcja zasadza się na innym źródle niż wzajemna umowa. Obcy moralnie muszą rozwiązać problemy moralne poprzez odwołanie do wzajemnej zgody, ponieważ nie dzielą ze sobą w wystarczającym stopniu światopoglądu, by móc odkryć merytoryczne rozwiązania pojawiających się dylematów moralnych: czy to poprzez odwołanie się do wspólnie wyznawanych zasad (łącznie z regułami dowodzenia i wnioskowania), czy też przez odwołanie się do jednostek lub instytucji, które powszechnie są uznawane za autorytet zdolny rozwiązać kontrowersje moralne i dać merytoryczne wskazania. Mimo to „obcy moralnie” nie muszą być dla siebie obcy. Mogą wzajemnie rozpoznawać swoje zobowiązania moralne i uznawać je za błędne lub nieuporządkowane. Różne hierarchie podstawowych wartości będą czyniły jednostki dla siebie obcymi moralnie, ale nie wzajemnie niezrozumiałymi. Ponadto, biorąc pod

Tadeusz Ślipko uznał, że „desygnatem terminu «etyka chrześcijańska» nie jest jakaś jedna określona «etyka», ale różne «etyki chrześcijańskie»", natomiast spośród nich wyłącznie pragmatycznie wyróżnił tomizm jako szczególnie rozbudowany i popularny nurt etyki chrześcijańskiej. Zob. T. Ślipko, Zarys etyki ogólnej, WAM, Kraków 2002, s. 7-9. 
uwagę złożoność sytuacji i ludzkich skłonności, obcy moralnie mogą być najbliższymi emocjonalnie przyjaciółmi ${ }^{10}$.

Upraszczając: moralna przyjaźń oparta jest na pełnej zgodzie co do fundamentalnych zasad epistemologicznych, racjonalnych i autorytatywnych. Stwierdzamy moralną przyjaźń, dostrzegając jakąś wspólną filozoficzną płaszczyznę, dzięki której można prowadzić merytoryczną i skuteczną dyskusję co do dylematów czy kontrowersji moralnych. Moralna przyjaźń oznacza zatem posiadanie wspólnej (tzn. takiej, co do której wszyscy uczestnicy debaty się zgadzają) platformy dyskusji: wspólnego i uzgodnionego zbioru pojęć, zasad wnioskowania czy racjonalnego argumentowania. A zatem moral friends nie muszą zgadzać się co do konkretnych rozstrzygnięć i norm etycznych, ale muszą rozumieć, dlaczego ich ocena się różni i pod jakimi warunkami mogliby ją zmienić.

Relacja moralnej obcości jest zupełnie inna: nie oznacza ona konieczności konfliktu, lecz ewentualna zgoda będzie zbudowana w zupełnie inny sposób niż zgoda pomiędzy moralnymi przyjaciółmi. „Moralnie obcych" dzieli przede wszystkim niemożność znalezienia wspólnej platformy dyskusji, niezgoda co do fundamentalnych zasad racjonalności lub rozumienia stosowanych pojęć. Rozwiązaniem konfliktu pomiędzy nimi nie jest zatem etyczna dyskusja, debata w celu ustalenia prawdy, lecz obopólny konsensus, forma umowy opartej nie na racjach i argumentach, lecz na umowie, zgodzie, a być może na demokratycznie uzyskanym kompromisie.

Jak łatwo się domyśleć, moim zdaniem, wspólnotę etyk chrześcijańskich powinniśmy rozumieć jako „moralną przyjaźń" pomiędzy poszczególnymi nurtami i tradycjami. Jasne jest, że pośród etyków proweniencji chrześcijańskiej mamy zwolenników arystotelizmu, platonizmu, neoplatonizmu, personalizmu, fenomenologii, a może nawet kantyzmu czy szkoły lwowsko-warszawskiej. Nie znajdziemy jakiejś wspólnej dla nich historycznej genezy; nie wyrastają one z jednego pnia, nie mają wspólnych korzeni. Wydaje się jednak, że można znaleźć „podobieństwo rodzinne" czy właśnie "moralną przyjaźń" pomiędzy nimi: nie są one skazane na stały konflikt ani też na jakieś negocjowanie ocen moralnych. Owa wspólnota oznacza przede wszystkim posiadanie pewnej wspólnej płaszczyzny porozumienia, wspólnego języka, wspólnych reguł racjonalności i zgody co do autorytetów. Na tym właśnie polega moralna przyjaźń łącząca wszystkie nurty, adekwatnie mogące uznawać się za należące do rodziny etyki chrześcijańskiej.

10 H. T. Engelhardt, The Foundations of Bioethics, OUP, New York 1996, s. 7. 


\section{Warunek drugi: chrześcijański kontekst odkrycia, filozoficzny kontekst uzasadnienia}

Istotny fakt zauważył i dobrze opisał w swoich książkach Jakub Gorczyca. „Ktoś, kto zapoczątkowuje refleksję nad kwestiami moralnymi, czyni to w sytuacji, która jest już nieodwracalnie naznaczona jego curriculum vitae, tradycją kulturowa, do której należy, okolicznościami dziejowymi, tożsamością rozmówców - także tych, których spotkał jedynie za pośrednictwem dostępnych lektur"11. Dotyczy to także myśliciela wyznającego chrześcijaństwo - jego etyka również jest „nieodwracalnie naznaczona” religią autora. Gorczyca określa to mianem „inspiracji heurystycznej"12. Wydaje się to czymś oczywistym i niezwykle trudnym do zanegowania - chyba, że przyjmuje się możliwość radykalnego oddzielenia utworu od twórcy, możliwość istnienia jakiejś „etyki czystej”, niezaangażowanej, radykalnie obiektywnej. Osobiście zgadzam się z Gorczyca, który stwierdził, iż „etyka, jak każda teoria filozoficzna nawet radykalnie racjonalistyczna - jest późniejsza od doświadczalnego kontaktu z rzeczywistością", co oznacza, że „abstrakcji filozoficznej nie dokonuje nigdy abstrakcyjny podmiot. I nikt zatem, kto rozpoczyna refleksję nad moralnościa, nie wychodzi od «punktu zerowego»"13. Tym punktem zerowym może być wiara chrześcijańska, ale może również być to ateizm, komunizm, liberalizm gospodarczy czy pacyfizm. Krótko mówiąc: doświadczenie, które ukształtowało etyka, kształtuje także jego etykę.

Chrześcijaństwo rzeczywiście może być o tyle szczególnym doświadczeniem, że nie tylko (jak każda religia) przenika wszystkie sfery życia człowieka, ale również - jako religia dominująca na naszym obszarze geograficznym - zdominowało całą kulturę euroamerykańską. Trudno sobie wyobrazić świat zachodni bez jego chrześcijańskich (obok grecko-rzymskich) korzeni. Jest to zatem relacja podwójna. $Z$ jednej strony „istnieją pojęcia, które de facto przychodzą do dziedziny filozoficznej z wiary chrześcijańskiej; są to na przykład pojęcia, takie jak osoba i stworzenie. Jako pojęcia filozoficzne byłyby one niezrozumiałe, gdyby nie można było wskazać na ich chrześcijańskie pochodzenie"14. Etyka europejska jest po prostu - czy to się nam podoba czy nie - w znacznej części ufundowana na pojęciach, ideach i normach chrześcijańskich. Ale s. 23.

11 J. Gorczyca, Zarys etyki fundamentalnej. Być dla drugiego, WAM, Kraków 2014,

12 Zob. ibidem, s. 30-33.

13 J. Gorczyca, Chrystus i ethos. Szkic o etyce filozoficznej w kondycji chrześcijańskiej, WAM, Kraków 1998, s. 49.

14 R. McInerny, Zagadnienie etyki chrześcijańskiej, przeł. R. Mordarski, Daimonion, Kęty 2004, s. 129. 
jednocześnie, co zauważa kolega McInerny'ego z University of Notre Dame: „chrześcijaństwo, proponując przekonania moralne i budując pojęcia moralne dla zwykłego życia ludzkiego, zadowalało się schematami pojęciowymi wziętymi skądinąd"15. To podwójne sprzężenie - kultury europejskiej z etyką chrześcijańską oraz etyki chrześcijańskiej z kulturą europejską - rodzi pokusę utożsamienia ich ze sobą. Byłby to jednak błąd. Istnieje bowiem dość precyzyjne kryterium (uznane przeze mnie za drugi warunek brzegowy), pozwalające odróżnić etykę chrześcijańską od niechrześcijańskich etyk euroamerykańskich, a jednocześnie od chrześcijańskiej teologii moralnej.

W 1938 roku Hans Reichenbach opublikował Experience and Prediction, którą rozpoczął od wprowadzenia słynnego rozróżnienia na „kontekst odkrycia" i „kontekst uzasadnienia"16. Jego istotą jest wskazanie na różnicę, często niedostrzeganą lub pomijaną: to, w jaki sposób odkrywamy jakieś prawdy, nie determinuje metody jej udowodnienia. Pierwszy kontekst (kontekst odkrycia) ma charakter subiektywny, często także psychiczny i społeczny; drugi natomiast (kontekst uzasadnienia) musi mieć wymiar obiektywny - a przynajmniej intersubiektywny - epistemologiczny, i w całości ma wypełniać normy metodologiczne danej dyscypliny ${ }^{17}$.

To rozróżnienie jest bardzo cenne także w perspektywie warunków brzegowych etyki chrześcijańskiej (odnosi się to oczywiście do całej filozofii chrześcijańskiej). Przymiotnik „chrześcijańska” może dotyczyć wyłącznie „kontekstu odkrycia”, podczas gdy w żaden sposób nie może mieć odniesienia do „kontekstu uzasadnienia”, który musi w całości spełniać wymagania stawiane etyce jako takiej. Aspekt „,chrześcijańskości” etyki polegał będzie na chrześcijańskim kontekście odkrycia: „Wiara chrześcijańska będzie podpowiadać myślicielowi podejmowanie pewnych projektów badawczych $w$ danej nauce. [...] A zatem filozofowanie chrześcijańskie nie daje połączenia wiary i wiedzy, lecz korzyść z wiedzy, która nigdy nie zostałaby zdobyta bez pomocy wiary"18. Niemiec będzie chętniej sięgał po pewne tematy, Polak zaś po inne; podobnie myśliciel będący np. ofiarą ludobójstwa w Kambodży czy kobieta-filozof. Tak samo wierzacy chrześcijanin będzie miał naturalne predylekcje do konkretnych problemów i zagadnień. Z tej perspektywy, jak pisał McInerny, etyka chrześcijańska nie jest jakimś połączeniem wiary z my-

15 A. MacIntyre, Krótka historia etyki. Filozofia moralności od czasów Homera do XX wieku, przeł. A. Chmielewski, PWN, Warszawa 2000, s. 162.

16 Zob. H. Reichenbach, Trzy zadania epistemologii, przeł. W. Sady, „Studia Filozoficzne" 1989, nr 7-8(284-285), s. 205-212.

17 Warto zauważyć, że jest to dość bliskie temu, co John Henry Newman nazywał rozumowaniem implikatywnym i eksplikatywnym.

18 R. McInerny, Zagadnienie etyki chrześcijańskiej, op. cit., s. 140. 
ślą filozoficzną (tak można określić raczej dzieło teologów), lecz jedynie filozoficzną analizą tematów inspirowanych chrześcijaństwem.

Tę jednokierunkową zależność pomiędzy chrystianizmem i etyką podkreślał Kazimierz Pawłowski: „wiara inspiruje twórczo filozofa, ale ani nie ogranicza jego badań i dociekań, ani nie determinuje rozwiązań"19. Wpływ ten może dotyczyć - powtórzmy - tylko odkrycia, nie uzasadnienia ani nawet nie ostatecznej oceny, opinii, normatywności etc. Trzeba tutaj bardzo uważać: jakakolwiek transgresja elementu chrześcijańskiego z kontekstu odkrycia na kontekst uzasadnienia unieważnia taką etykę chrześcijańską. To kryterium pokazuje, jak trudne jest uprawianie filozofii i etyki chrześcijańskiej: przecież nie istnieją żadne „chrześcijańskie argumenty”. Każdy przedstawiciel etyki chrześcijańskiej musi wspierać swoje rozumowanie tak samo, jak myśliciel z jakiegokolwiek innego nurtu etycznego: posługując się argumentami zrozumiałymi i sensownymi tak dla chrześcijan, jak i dla niechrześcijan ${ }^{20}$.

Ten drugi warunek brzegowy filozofii i etyki chrześcijańskiej być może najlepiej wyraził Étienne Gilson w słynnym Duchu filozofii średniowiecznej: „Filozof chrześcijański po prostu zadaje sobie tylko pytanie: czy wśród tych twierdzeń, w których prawdziwość wierzy, nie znajdują się takie, o których prawdziwości jego rozum mógłby się przekonać? Dopóki człowiek wierzący opiera swoje twierdzenia na wewnętrznym przekonaniu czerpanym z wiary, nie wkroczył jeszcze w dziedzinę filozofii. Z chwila jednak, gdy wśród przedmiotów swej wiary odkrywa pewną liczbę prawd mogących stać się przedmiotem poznania - staje się filozofem. Jeśli zaś te nowe zdobycze filozoficzne zawdzięcza wierze chrześcijańskiej - staje się filozofem chrześcijańskim”"21. Czy nie pobrzmiewa nam tutaj ta sama para „wiara-rozum”, z którą tak mocno siłowali się myśliciele średniowieczni i do której odwołał się już we wspomnianej encyklice Jan Paweł II? Chrześcijaństwo z całą pewnością zawiera elementy objawione, które przyjmujemy na drodze wiary; ale wyraża również bardziej uniwersalne prawdy - dotyczące choćby antropologii czy moralności - które mogą zostać wyjaśnione i przyjęte bez odwoływania się do Objawienia, a więc na drodze rozumowej. Etyka chrześcijańska to zatem rozumowe przedstawienie, analiza i uzasadnienie tych kwestii moralnych, które w jakiś (jakikolwiek?) sposób pochodzą z inspiracji chrześcijaństwem, jako jej „kontekst odkrycia”.

19 K. Pawłowski, Wprowadzenie, w: K. Szałata, Filozofia chrześcijańska. Na marginesie wielkiej debaty od encykliki "Aetarni Patris" do "Fides et ratio", Fundacja Polska Raoula Follereau, Warszawa 2004, s. 7.

20 Zob. K. E. Løgstrup, The Ethical Demand, przeł. T. I. Jensen i inni, University of Notre Dame Press, Notre Dame-London 1997, s. 111.

21 É. Gilson, Duch filozofii średniowiecznej, przeł. J. Rybałt, PAX, Warszawa 1958, s. 37. 


\section{Warunek trzeci: niesprzeczność z doktryną chrześcijańskq}

Być może najbardziej kontrowersyjny jest warunek trzeci, zakładający, iż tylko ten nurt można określić mianem etyki chrześcijańskiej, którego wnioski i tezy nie pozostają w sprzeczności z doktryną chrześcijańską.

Niektórzy ten warunek stawiali jeszcze ostrzej. Nawet tak uznany historyk, jakim był Frederick Copleston, stwierdza: „Wyrażenie «filozofia chrześcijańska» może co najwyżej oznaczać w sposób uprawniony tylko to, że filozofia ta jest zgodna z chrześcijaństwem; jeżeli oznacza coś więcej, mówi się wtedy o filozofii, która nie jest wyłącznie filozofią lecz przynajmniej częściowo także teologią"22. A zatem tradycja, którą reprezentował Copleston, poprzeczkę stawia bardzo wysoko: tylko tę filozofię czy etykę można określić mianem chrześcijańskiej, której doktryna jest zgodna z Objawieniem i nauczaniem chrześcijańskim. Myślę, że dziś ta teza jest nie do utrzymania $-\mathrm{z}$ dwóch powodów. Po pierwsze, dlatego, że żyjemy w czasach, w których filozofia walczy o samodzielność, o pozycję niezależnej, merytorycznej i naukowej dyscypliny ludzkiej myśli. Uznanie, że może istnieć pełna zgodność pomiędzy etyką z jednej strony i religią z drugiej, jest w potocznym odbiorze degradujące dla tej pierwszej.

Ważniejszy jednak jest drugi powód sprzeciwu wobec kryterium zgodności. Krótko wyraża go polski filozof i kosmolog Michał Heller: „Zauważmy, że znacznie łatwiej rozstrzygnać, jaka filozofia jest sprzeczna z twierdzeniami religii chrześcijańskiej, niż orzec, że jakaś filozofia jest z nimi zgodna. Na przykład każda filozofia ateistyczna jest jawnie niezgodna z chrześcijaństwem". Natychmiast dodaje jednak bardzo istotne zastrzeżenie: "Jednakże to negatywne kryterium sprawia, że zbyt wiele różnych filozofii może kandydować do miana filozofii chrześcijańskiej. Jak spośród nich wybrać te «naprawdę zgodne»?"23. Przyjrzyjmy się obu tym tezom.

Potwierdzenie zgodności etyki i chrześcijaństwa wymagałoby jakiegoś oficjalnego autorytetu stwierdzającego o kompatybilności danego systemu czy dzieła z doktryną chrześcijańską. Dużo łatwiej stwierdzić istniejącą niezgodność - wystarczy przecież wskazanie jednej tezy czy wniosku sprzecznego z uznaną prawdą wiary, by przymiotnika „,chrześcijańska" danej etyce odmówić. Więc z powodów zarówno filozoficznych, jak i pragmatycznych należy osłabić kryterium zgodności do

${ }^{22}$ F. Copleston, Historia filozofii, t. 2, przeł. S. Zalewski, PAX, Warszawa 2004, s. 497.

${ }^{23}$ M. Heller, Sens życia $i$ sens wszechświata. Studia z teologii wspótczesnej, Biblos, Tarnów 2002, s. 55. 
kryterium niesprzeczności. Rodzi to jednak drugi problem podniesiony przez Hellera: czy ten bardziej liberalny warunek nie jest zbyt słaby, czy nie dopuszcza on zbyt szerokiego spektrum etyk chrześcijańskich? Owszem, trzeci warunek brzegowy sam w sobie nie stanowi warunku wystarczającego, a jedynie konieczny. Skoro jednak główna teza niniejszego artykułu stanowi, iż nie da się wskazać jednej, prostej definicji, lecz konieczne jest przedstawienie kilku warunków brzegowych, które łą c z n i e pozwalają odróżnić etyki chrześcijańskie od niechrześcijańskich, nasza robocza odpowiedź na pytanie Hellera „jak spośród nich wybrać te «naprawdę zgodne»?" brzmi: posługując się pozostałymi czterema warunkami.

Najpierw należy zrozumieć, czym miałoby być owo kryterium niesprzeczności z doktryną chrześcijańską. Przede wszystkim stanowi ono „zewnętrzne, czyli pozafilozoficzne kryterium negatywne”24. Wszystkie trzy słowa są tutaj ważne: warunek trzeci jest czynnikiem z e w n ę t r zn y m - bez względu na intencję uprawiania etyki chrześcijańskiej (koniunkturalizm, ciekawość, osobiste przekonania), owa „chrześcijańskość" zawsze jest pewnym niekoniecznym dodatkiem, czymś, co nie należy do istoty etyki i co można zarówno przyjąć, jak i odrzucić. Wynika to $\mathrm{z}$ drugiej cechy: jest kryterium $\mathrm{p}$ o z a f i 1 o z o f i c z n y m, czyli nie wynikającym z przyjętych założeń filozoficznych, obiektywnych i merytorycznych, a z pewnych założeń przedfilozoficznych, mających swe źródło w wyznawanej wierze, tradycji, w której się wychowaliśmy, boskim objawieniu etc. Oznacza to równocześnie, że decyzja o przyjęciu kryterium niesprzeczności etyki z chrześcijaństwem nie może zostać obalona na drodze krytyki filozoficznej (można co najwyżej starać się obalić prawomocność chrześcijaństwa jako systemu religijnego). I wreszcie: kryterium to ma tylko i wyłącznie charakter n e g a t y w n y , a zatem dzięki niemu możemy powiedzieć, który system nie należy do rodziny etyk chrześcijańskich, ale nie pozwala nam on stwierdzić, że coś do niej przynależy.

Zgadzając się z obowiązywaniem tego warunku („filozofię chrześcijańską stanowi sposób filozofowania [...] zakładający niesprzeczność pomiędzy racjonalnym porządkiem wiedzy a prawdami objawienia chrześcijańskiego"25), Wojciech Chudy ciekawie rozwinął ten warunek. „Niesprzeczność z prawdami wiary” oznacza, że w etyce chrześcijańskiej „Objawienie pełni rolę zewnętrznoheurystyczną oraz negatywnokontrolującą" ${ }^{26}$. Doktryna chrześcijańska wypełnia zatem zadanie

24 Z. J. Zdybicka, E. I. Zieliński, Chrześcijańska filozofia, w: Powszechna Encyklopedia Filozofii, red. A. Maryniarczyk, t. 2, Polskie Towarzystwo Tomasza z Akwinu, Lublin 2001, s. 170.

25 W. Chudy, Filozofia chrześcijańska, op. cit., s. 45.

26 Ibidem, s. 59. 
nie tylko wspólnototwórcze (warunek pierwszy) i inspirujące (warunek drugi), ale również negatywnokontrolujące (warunek trzeci), czyli falsyfikuje nieuprawnione aspiracje do nazwy „etyka chrześcijańska”. Ostatecznie chodzi zatem o uznanie lub odrzucenie autorytetu, jakim cieszy się Objawienie ${ }^{27}$. O ile jednak teologia przyjmuje autorytatywność doktryny chrześcijańskiej tak w aspekcie pozytywnym, jak i negatywnym, o tyle filozofia i etyka chrześcijańska uznaje ten autorytet wyłącznie w wymiarze negatywnym: sprzeczność z doktryną wyklucza z rodziny filozofii chrześcijańskiej, ale jednocześnie chrystianizm nie ma prawa wymagać od chrześcijańskiego etyka zgodności wszystkich jego tez z Objawieniem.

\section{Warunek czwarty: wspólne cele}

Wojciech Chudy stawia dość kontrowersyjną tezę: „filozofię chrześcijańską stanowi sposób filozofowania przyjmujący maksymalistyczne zadania poznawcze ${ }^{28}$. Czy rzeczywiście możemy powiedzieć, że różnica pomiędzy etyką chrześcijańską a niechrześcijańskimi polega nie tylko na odmiennych inspiracjach, ale także na innych zadaniach? Przecież wydaje się, że głównym celem etyki jako etyki (podobnie zresztą jak pozostałych gałęzi filozofii) jest poznanie prawdy. Czy oprócz tego można dodać jeszcze jakieś inne cele? Czy ostatecznie nie przesłonią one podstawowej misji? I co miałyby oznaczać owe „maksymalistyczne zadania poznawcze"?

Rozpocznijmy od ostrożniej postawionej tezy: każdy nurt filozoficzny ma swoje własne, szczególnie interesujące cele poznawcze. Czymś dość oczywistym jest, że etyka feministyczna będzie przede wszystkim interesowała się kwestiami dotyczącymi kobiet, a ekofilozofia - sprawami środowiska naturalnego. Czy inaczej miałoby być w przypadku etyki chrześcijańskiej? „Filozof chrześcijański to przede wszystkim człowiek dokonujący wyboru między zagadnieniami filozoficznymi; jest to może najbardziej znamienny rys jego postawy. W zasadzie może on, jak każdy inny filozof, interesować się całokształtem problematyki, w praktyce jednak będzie się interesował wyłącznie lub szczególnie tymi zagadnieniami, których rozwiązanie ma jakieś znaczenie dla jego życia

27 Oczywiście sama kwestia zakresu i źródeł autorytetu religii chrześcijańskiej również podlega dyskusji. Na potrzeby niniejszego tekstu wystarcza bardzo ogólne i robocze wymienienie czterech podstawowych (,pośród wielu innych”) źródeł etyki chrześcijańskiej: Biblii, tradycji, doświadczenia i danych naukowych. Zob. P. B. Jung, L. S. Jung, Moral issues and Christian responses, Fortress Press, Minneapolis 2013, s. 17.

28 W. Chudy, Filozofia chrześcijańska, op. cit., s. 45. 
religijnego" ${ }^{29}$. Trudno, żeby było inaczej, jeśli ktoś decyduje się określać uprawianą etykę mianem chrześcijańskiej. Mieczysław Gogacz wymienił nawet szczególnie powszechne wśród myślicieli chrześcijańskich „zagadnienia filozoficzne, które interesują ich jako chrześcijan, np. zagadnienie przyczyn, uwyraźniające problem Boga, podobnie zagadnienie bytowej struktury człowieka i w tej strukturze status duszy"30. Te tematy są jednak interesujące nie tyle dla myślicieli chrześcijańskich, ile raczej teistycznych: te same znajdziemy u średniowiecznych filozofów żydowskich czy muzułmańskich. Znacznie bardziej wartościowe wydają się dwa inne głosy (co ciekawe, oba wyliczają po trzy cele/zadania/ /sensy systemów proweniencji chrześcijańskiej).

Pierwsza lista ${ }^{31}$, stworzona przez hiszpańskiego jezuitę Juana Roig Gironelliego, wymienia „trzy wymiary sensu” myśli chrześcijańskiej. Po pierwsze, jej zadaniem jest "oczyszczenie drogi", czyli zbadanie, które nurty filozoficzne (resp. etyczne) są z perspektywy chrześcijańskiej całkowicie nieprzydatne. Po drugie, jej obowiązkiem jest pozostawanie w bliskim kontakcie z najbardziej aktualnymi naukami szczegółowymi i nurtami humanistycznymi - oraz (w miarę możliwości) współpraca z nimi. Trzecim celem jest wykazywanie granic ludzkiej racjonalności i konieczności przekraczania jej w celu znalezienia odpowiedzi na najbardziej żywotne pytania człowieka.

Nieco inną listę przedstawił Andrzej Miś32, wspominając o trzech zadaniach chrześcijańskiej filozofii i etyki. Po pierwsze, mają przekładać prawdy objawione na język pojęć świeckich („przeżycie religijne jest źródłowym doświadczeniem, które filozof pragnie wypowiedzieć w słowach coraz bardziej precyzyjnych i zrozumiałych"). Po drugie, myśl chrześcijańska polega na twórczym zastosowaniu prawd objawionych do rozwikłania współczesnych pytań. I wreszcie, etyk chrześcijański ma nie tylko budować, ale również burzyć, czyli „poddawać krytyce te koncepcje filozoficzne, które albo występują jawnie przeciwko prawdom wiary, albo noszą w sobie - czego niekiedy sami ich autorzy się nie domyślają - zalążek filozoficznej herezji".

Jak łatwo zauważyć, obie listy nie przeczą sobie i w znacznym stopniu pozostają zbieżne - także z wcześniejszymi słowami Gogacza. Nie mam zamiaru bronić żadnej z nich, co więcej: uważam, że czwarty warunek etyki chrześcijańskiej - zbieżność celów - jest szczególnie kontrowersyjny: czy rzeczywiście możemy wskazać jakieś szczególne, fundamentalne zadania charakteryzujące etykę chrześcijańską jako chrześcijańską?

29 É. Gilson, Duch filozofii średniowiecznej, op. cit., s. 39.

30 M. Gogacz, Czym jest filozofia chrześcijańska, op. cit., s. 6.

31 Zob. M. Jędraszewski, Jak należy rozumieć pojęcie "filozofia chrześcijańska", "Filozofia Chrześcijańska" 2004, nr 1, s. 12.

32 Zob. A. Miś, Filozofia wspótczesna: główne nurty, Scholar, Warszawa 2006, s. 169. 
Niemniej chyba zgodzimy się z Gilsonem, że tak jak każdy nurt etyczny posiada tematy mu najbliższe, najbardziej go interesujące, tak też myśl chrześcijańska będzie miała szczególną predylekcję ku kwestiom bioetycznym, relacji nauka-wiara, teoriom prawa naturalnego, cnót czy sumienia. Listy tej jednak nie należy traktować jako zamkniętego, dogmatycznie zdefiniowanego warunku sine qua non.

\section{Warunek piąy: katolickość}

Jeśli warunek czwarty posiada niższy status niż trzy wcześniejsze, to kryterium piąte znajduje się jeszcze niżej, będąc raczej cechą charakterystyczną etyki chrześcijańskiej niż warunkiem koniecznym lub nawet wystarczającym. Niemniej wydaje się, że warto o niej wspomnieć - postulując wręcz, by była uznawana za wypływającą z warunku pierwszego, czyli z moralnej przyjaźni pomiędzy poszczególnymi nurtami należącymi do rodziny etyki chrześcijańskiej.

„Oto największa zasługa, jaką można przypisać etyce chrześcijańskiej: odkrycie nowej równowagi” - pisał Gilbert Keith Chesterton. „Pogaństwo przypominało marmurową kolumnę, która trzymała się w pionie dzięki symetrii i doskonałej proporcji kształtów. Chrześcijaństwo okazało się natomiast podobne do wielkiego, romantycznie nieforemnego głazu, który co prawda chwieje się pod dotknięciem ręki, ale dzięki doskonałej równowadze nieregularnych wypukłości może królować na swoim miejscu tysiąc lat. W gotyckiej katedrze każda kolumna wyglądała inaczej, a jednak każda była niezbędna. Każdy ze wsporników wydawał się przypadkowy i fantastyczny; każda z przypór wyginała się nieprawdopodobnym łukiem. Tak samo w chrześcijaństwie pozorne przypadkowości równoważyły się nawzajem"33. Ten poetycki obraz wydaje się bardzo interesujący i inspirujący. Przeciwstawia on sobie dwa modele: etykę antyczna, przedchrześcijańska, którą cechowała doskonałość proporcji i symetrii, etyce chrześcijańskiej, w której nie ostało się nic z tego subtelnego, wręcz matematycznego piękna. Zdaniem Chestertona, skuteczność i trwałość etyki chrześcijańskiej nie wynika $\mathrm{z}$ jej formalnej doskonałości, lecz $\mathrm{z}$ tego, co on określa mianem n o w e j ró w n ow a gi.

Polega ona na harmonijnej współpracy, połączeniu czy koegzystencji różnych elementów, "pozornych przypadkowości”, które pasują do siebie nie jak puzzle, lecz raczej na mocy ich niezbędności dla podtrzymania całości. Na ten sam fakt zwraca uwagę dwóch innych uznanych myślicieli. Pierre Hadot stwierdza wprost, że „to, co rozproszone, roz-

33 G. K. Chesterton, Ortodoksja. Romanca o wierze, przeł. M. Sobolewska, Fronda-Apostolicum, Warszawa-Ząbki 2004, s. 173-174. 
bite na kawałki w filozofii greckiej, w filozofii chrześcijańskiej jest zsyntetyzowane i usystematyzowane" ${ }^{\prime 34}$. A zatem jako obraz etyki chrześcijańskiej - obok Chestertonowskiej średniowiecznej katedry - może posłużyć quilt czy patchwork: nie stanowią one jednolitego, naturalnego systemu, lecz raczej „pogodzoną różnorodność”, w której rozmaite elementy zostają ze sobą w twórczy, oryginalny i pragmatycznie skuteczny sposób „zsyntetyzowane i usystematyzowane”.

Jeszcze inny model - lecz całkowicie zbieżny z dwoma powyższymi - znajdziemy u Hansa Ursa von Balthasara:

To, że prawda chrześcijańska jest symfoniczna, jest zatem być może czymś najbardziej koniecznym, co należy dzisiaj głosić i wprowadzać w czyn. Symfonia nie oznacza bynajmniej ckliwej, pozbawionej napięć harmonii. Wielka muzyka jest zawsze dramatyczna, to coś bezustannie kłębiącego się i niosącego ze sobą zanikanie napięć na wyższym poziomie. Dysonans nie jest jednak kakofonią. Nie jest też jedynym środkiem podtrzymywania symfonicznego napięcia. Mozart nadaje swojej najprostszej melodii - jakże często posługuje się on prostymi gamami - coś tak bardzo sprężystego, wewnętrznie wzburzonego, spiętego w sobie, że siła, po której rozpoznaje się jego muzykę już po kilku taktach, zdaje się wypływać z niewyczerpanego źródła błogosławionego napięcia ${ }^{35}$.

Von Balthasar zdaje się sugerować, że istnieje swoista oryginalność „prawdy chrześcijańskiej” i że polega ona na dramatyczności, wewnętrznym napięciu, równoważeniu się przeciwieństw. Greckie oú $\mu \phi \omega v o \varsigma$ dosłownie oznacza współbrzmienie, zgodę pomiędzy dźwiękami - a zatem symfoniczność etyki chrześcijańskiej oznaczałaby swoistą harmonię pomiędzy nietożsamymi elementami, współbrzmienie części, które nie są związane ze sobą pochodzeniem czy natura, lecz poprzez wspólny dla nich cel, pragmatyczną skuteczność, wzajemne uzupełnianie swych braków.

Średniowieczna katedra, patchwork, symfonia. Co te trzy obrazy mają ze sobą wspólnego? Pozwolę sobie zaryzykować i postawić dość odważną tezę: wszystkie je łączy to, co określamy jako "katolickość". Nie mam tu na myśli przymiotnika określającego konkretną denominację chrześcijańska, lecz to, od czego owo wyznanie wzięło swoją nazwę. Sięgnijmy do świetnej książki niedawno zmarłego amerykańskiego teologa, w uznaniu jego dokonań mianowanego pod koniec życia kardynałem. Avery Dulles, bo o nim mowa, poświęcił pracę The Catholicity of the Church rozważaniom nad znaczeniem przymiotnika „katolicki”. Cieka-

34 P. Hadot, Filozofia jako ćwiczenie duchowe, przeł. P. Domański, Aletheia, Warszawa 2003 , s. 72 .

35 H. U. von Balthasar, Prawda jest symfoniczna. Aspekty chrześcijańskiego pluralizmu, przeł. I. Bokwa, W drodze, Poznań 1998, s. 11. 
wie wygląda definiowanie przymiotnika „katolicki” poprzez wskazanie jego przeciwieństw ${ }^{36}$. Dulles wykazuje, że to, co katolickie jest ze swej natury przede wszystkim w opozycji do tego, co 1) se k ciarskie („,być katolickim w tym znaczeniu to mieć udział w uniwersalnej wspólnocie, być zakorzenionym $\mathrm{w}$ kosmicznej naturze, przekraczać granice czasu i przestrzeni”); 2) lo k a ln e lub partykula rne (,katolickie" przekracza to, co jedynie częściowe lub lokalne); lub temu, co 3) f ałs z y we lub he re ty c k i e (,katolicki” oznaczałby zatem ",prawdziwy" i "autentyczny"). Wynika z tego, że katolickość ma znaczenie wybitnie inkluzywne: wyłączone może być jedynie to, co fałszywe, nieautentyczne, bądź z definicji nie roszczące sobie pretensji do uniwersalności.

W tej samej książce znajdziemy utożsamienie katolickości z pełnia, jednością przeciwieństw w opozycji do „niepełności, cząstkowości, pomniejszenia, frakcyjności, sekciarstwa i heretyckiej selektywności"137. A zatem katolickość - potocznie przekładana na język polski jako powszechność lub uniwersalność - oznacza gotowość do włączania różnorodnych elementów, które nie są wzajemnie sprzeczne, lecz mimo różnorodnych napięć współbrzmią ze sobą (von Balthasar), mogą tworzyć nową równowagę (Chesterton) oraz dają się zsyntetyzować i usystematyzować (Hadot). Doskonale scharakteryzował to Dulles, pisząc, że katolickość oznacza przyjęcie raczej perspektywy „zarówno/i” niż „tyl$\mathrm{ko} / \mathrm{lub}^{\prime \prime 38}$. Tak też proponuję rozumieć ostatni warunek przynależności do rodziny etyk chrześcijańskich - nurt ten otwarty jest na korzystanie z nowych doświadczeń, łączenie w jedną całość „tego, co rozproszone, rozbite na kawałki", równoważąc elementy mające bardzo różne pochodzenie, pozornie przypadkowo zebrane razem. Etyka chrześcijańska właśnie w swoim wymiarze katolickości - nie obawia się ryzyka takiego inkluzywizmu, nie unika prób godzenia ognia z woda, mając na celu zawsze odkrywanie prawdy o ludzkim postępowaniu, o dobru i złu moralnym, o tym, co jako podmiot moralny powinienem robić, a czego unikać.

\section{Zakończenie}

Niniejszy tekst zamyka kilkuletnie badania dotyczące idei etyki chrześcijańskiej. Dwa wcześniejsze artykuły (wymienione we wstępie) badały możliwość istnienia filozofii o proweniencji chrześcijańskiej oraz relację etyki chrześcijańskiej do moralności chrześcijańskiej, teologii moralnej

36 A. Dulles, The Catholicity of the Church, Clarendon Press, Oxford 1987, s. 185.

37 Ibidem, s. 8.

38 Ibidem, s. 3. 
i nurtów etyki niechrześcijańskiej. Powyższa publikacja bada z kolei warunki konieczne do uznania danego systemu czy nurtu za pełnoprawną etykę chrześcijańską. Przedstawione tu pięć kryteriów - z których trzy pierwsze wydają się mieć charakter bezwzględnie obowiązujący, a dwa kolejne przedstawiają fundamentalne, choć do pewnego stopnia przygodne cechy - ma łącznie dać precyzyjne narzędzie do odróżnienia etyki chrześcijańskiej od teologii z jednej strony, a z drugiej: od etyki niechrześcijańskiej.

Być może te warunki da się określić bardziej subtelnie, dokładniej; może też któryś z nich jest chybiony lub też na liście brakuje jakiegoś dodatkowego kryterium. Etyka ma bowiem tę przewagę nad pozostałymi dyscyplinami filozoficznymi, że jest najbliżej potocznego życia. Ma więc charakter nie tylko teoretyczny, lecz również - a może przede wszystkim - praktyczny. Owe pięć warunków brzegowych etyki chrześcijańskiej należy zatem testować na drodze abstrakcji, analizy filozoficznej, ale również poprzez badanie jej skuteczności w życiu codziennym.

Istniejące $\mathrm{w}$ Polsce naukowe instytucje przyznające się do bycia rzecznikiem filozofii i etyki chrześcijańskiej - m.in. Wydział Filozofii Chrześcijańskiej UKSW, Zakład Filozofii Chrześcijańskiej UAM i wydawany tam rocznik „Filozofia Chrześcijańska”, czy najmłodsze z nich Centrum Etyki Chrześcijańskiej z wydawaną serią „Universum Ethicæ Christianæ" - potrzebują sprawnego narzędzia umożliwiającego im zakreślenie granic swoich zainteresowań. Ponieważ do tej pory nie udało mi się znaleźć satysfakcjonującej definicji etyki chrześcijańskiej, postanowiłem po długotrwałych studiach zaproponować własną. Jest ona zawarta w powyższej liście pięciu warunków brzegowych etyki chrześcijańskiej.

\section{Bibliografia}

Chesterton G. K., Ortodoksja. Romanca o wierze, przeł. M. Sobolewska, Fronda-Apostolicum, Warszawa-Ząbki 2004.

Chudy W., Filozofia chrześcijańska - rozum i wiara, „Ethos” 2007, z. 3-4(79-80), s. $45-66$.

Copleston F., Historia filozofii, t. 2, przeł. S. Zalewski, PAX, Warszawa 2004.

Duchliński P., Kobyliński A., Moń R., Podrez E., Inspiracje chrześcijańskie w etyce, WAM, Kraków 2016

Dulles A., The Catholicity of the Church, Clarendon Press, Oxford 1987.

Durczewski J., Z refleksji nad chrześcijańska myśla filozoficzna (Geneza - rozwójaktualność), „Acta Universitatis Nicolai Copernici. Filozofia”, t. 143, 1983, z. 7, s. 135-152.

Engelhardt H. T., The Foundations of Bioethics, OUP, New York 1996. 
Gałecki S., O możliwości istnienia filozofii chrześcijańskiej, „Ruch Filozoficzny”, t. 72, 2016, nr 3, s. 117-132.

Gałecki S., Etyka chrześcijańska i jej rodzina, w: Etyka chrześcijańska - między tradycja a wspótczesnościa. Studia i szkice, P. Duchliński, E. Podrez (red.), WAM, Kraków 2016, s. 93-123.

Gilson É., Duch filozofii średniowiecznej, przeł. J. Rybałt, IW Pax, Warszawa 1958.

Gogacz M., Czym jest filozofia chrześcijańska, "Za i Przeciw” 1981, nr 14(5 kwietnia), s. 6, 23.

Gorczyca J., Chrystus i ethos. Szkic o etyce filozoficznej w kondycji chrześcijańskiej, WAM, Kraków 1998.

Gorczyca J., Zarys etyki fundamentalnej. Być dla drugiego, WAM, Kraków 2014.

Hadot P., Filozofia jako ćwiczenie duchowe, przeł. P. Domański, Aletheia, Warszawa 2003.

Heller M., Sens życia i sens wszechświata. Studia z teologii wspótczesnej, Biblos, Tarnów 2002.

Jan Paweł II, Encyklika „Fides et ratio" do biskupów Kościoła katolickiego o relacjach między wiara a rozumem, Rzym 1998.

Jędraszewski M., Jak należy rozumieć pojęcie "filozofia chrześcijańska”, "Filozofia Chrześcijańska” 2004, nr 1, s. 7-17.

Jung P. B., Jung L. S., Moral issues and Christian responses, Fortress Press, Minneapolis 2013.

Løgstrup K. E., The Ethical Demand, przeł. T. I. Jensen i inni, University of Notre Dame Press, Notre Dame-London 1997.

MacIntyre A., Krótka historia etyki. Filozofia moralności od czasów Homera do XX wieku, przeł. A. Chmielewski, PWN, Warszawa 2000.

McInerny R., Zagadnienie etyki chrześcijańskiej, przeł. R. Mordarski, Daimonion, Kęty 2004, s. 129.

Miś Andrzej, Filozofia wspótczesna: główne nurty, Scholar, Warszawa 2006.

Pawłowski K., Wprowadzenie, w: K. Szałata, Filozofia chrześcijańska. Na marginesie wielkiej debaty od encykliki "Aetarni Patris" do "Fides et ratio", Fundacja Polska Raoula Follereau, Warszawa 2004, s. 1-7.

Reichenbach H., Trzy zadania epistemologii, przeł. W. Sady, „Studia Filozoficzne" 1989, nr 7-8(284-285), s. 205-212.

Stachewicz K., O filozofii chrześcijańskiej. Kilka uwag z perspektywy historycznej i futurologicznej, „Logos i Ethos” 2013, nr 2(35), s. 219-234.

Ślipko T., Zarys etyki ogólnej, WAM, Kraków 2002.

von Balthasar H. U., Prawda jest symfoniczna. Aspekty chrześcijańskiego pluralizmu, przeł. I. Bokwa, W drodze, Poznań 1998.

Zdybicka Z. J., Zieliński E. I., Chrześcijańska filozofia, w: Powszechna Encyklopedia Filozofii, A. Maryniarczyk (red.), t. 2, Polskie Towarzystwo Tomasza z Akwinu, Lublin 2001, s. 167-173. 


\section{Streszczenie}

Idea etyki chrześcijańskiej istnieje od niemal dwudziestu wieków, jednak dopiero od kilkudziesięciu lat jej prawomocność jest powszechnie podważana, co zostało pokazane $\mathrm{w}$ artykule $O$ możliwości istnienia filozofii chrześcijańskiej. Do rozwiązania tej kontrowersji nie należy wyłącznie polemika z przeciwnikami sformułowania „etyka chrześcijańska”, ale również przedstawienie takiego rozumienia chrześcijańskiej filozofii moralnej, które unika błędów i słabości krytykowanych przez jej oponentów. Ponieważ niemożliwe jest podanie jednej, równościowej definicji, w niniejszym artykule zaproponowano pięć warunków brzegowych etyki chrześcijańskiej, pozwalających ją odróżnić zarówno od innych teorii etycznych, jak i od moralności lub teologii chrześcijańskiej.

Słowa kluczowe: etyka chrześcijańska, metaetyka, moralna przyjaźń, moralna obcość, kontekst odkrycia i kontekst uzasadnienia, katolickość

\section{Summary}

\section{The Boundary Conditions of a Christian Ethics}

The idea of Christian ethics has existed for almost twenty centuries, but for the last few decades its legitimacy has been widely undermined, as was shown in the paper entitled On the Possibility of Existence of a Christian Philosophy. The solution of this controversy is not only the polemic with opponents of the phrase "Christian ethics" but also adequate presentation of such an understanding of Christian moral philosophy which avoids the mistakes and weaknesses tainted by its opponents. Since it is impossible to give one intentional definition, this article proposes five boundary conditions for Christian ethics, thus allowing distinguish it from other ethical theories as well as from Christian morality or theology.

Keywords: Christian ethics, metaethics, moral friends, moral strangers, context of discovery and context of justification, catholicity 